\title{
The Government Policy on Foreign Direct Investment in Sri Lanka
}

\author{
* K. M. Panditharathna, ** Dr. Lakmini V.K. Jayatilake \\ *Assistant Lecturer-Department of Commerce and Financial Management, Faculty of Commerce and \\ Management Studies, University of Kelaniya, Sri Lanka. \\ ** Senior Lecturer-Department of Commerce and Financial Management, Faculty of Commerce and \\ Management Studies, University of Kelaniya, Sri Lanka.
}

\begin{abstract}
Unlike other forms of capital inflows, FDI almost always brings additional resources such as technology, management know-how, and access to export markets-that are desperately needed in developing countries. However foreign capital can play an important role in raising investment levels so as to accelerate economic growth in Sri Lanka as in the case of many other developing countries which are handicapped by inadequate domestic savings. The purpose of this study is to examine the Government Policy on Foreign Investment in Sri Lanka. FDI increased initially due to the favourable investment environment created by the 1977 reforms. During the 1983-89 period, the incentives for FDI were eroded by the setbacks in the foreign trade and payments liberalisation momentum and the macroeconomic disequilibrium. Even though FDI was felt down in year 2000, there were increasing trend in FDI up to year 2008 and FDI was diminished as a result of global financial crisis in year 2009. Basically due to the secure macroeconomic environment, Sri Lanka reached highest level of FDI in 2014. The prospect for a significant expansion of FDI inflows in to Sri Lanka, however, do not seems too bright. To attract further investment, it is paramount that Sri Lanka be able to provide policy stability.
\end{abstract}

Keywords: Foreign Direct Investment (FDI), Economic Development, Investment, Policy, Sri Lanka

\section{Introduction}

Foreign Direct Investment (FDI) is play an important role in economic development. Closed economy do not allow access to foreign savings. Therefore such economy has to finance through domestic savings. But in an open economy investment can be finance using domestic sources as well as using foreign savings. There are two kinds of foreign savings, they are; official foreign saving and private foreign saving. Foreign grants and foreign aids are coming under official foreign savings and private foreign savings can be categorize as external commercial borrowings, portfolio investment and foreign direct investment. Through FDI emerging countries be able to achieve higher FDI level than their capacity.

Infrastructure facilities of a country are directly influence to upturn the productivity as well as economic development. Therefore infrastructure facilities such as roads, telecommunication services, electricity, and water supply are essential to the economic development. In 1977 Sri Lanka introduced open market economy and FDI industrialization but most of other south Asian countries introduced FDI liberalization policies after year 1980. When compare with other south Asian countries with Sri Lanka concerned US \$ 40 million annual average FDI inflows (Jayathilake, 1999)

With the purpose of stimulating domestic investment and industrialization process in Sri Lanka main objective of this study is to examine the Government Policy on Foreign Investment in Sri Lanka. In order to achieve this objective, study has evaluated the Foreign Investment policy in the period after independence, and during the period of 1977 to 2015.

\section{Foreign Investment Policy before 1977}

Since independence, various governments of Sri Lanka have issued policy statement regarding foreign investments. Some of these documents have come out as White papers devoted to the subjects and others were included in the Budget Speeches. All policy statements in that area have given indications as to several important questions that arise when considering the subject of foreign investment. These include: the area of which foreign investments are invited, the relationship of foreign capital to local capital, investment guarantees, regulations regarding movements of funds and tax incentives.

The budget speech 1949-50 is one of the first documents in post-independent Sri Lanka that included a section which spelled out a specific state policy regarding foreign capital. There was a general, open invitation to foreign capital and, “...... the government has framed its policy not only to enable further foreign capital to be invested in Ceylon, on particular felids of investment in which the aid of foreign investment is desirable, and 
under conditions which safeguard the mutual interests already existing in Ceylon, to apply the same principles." (Budget Speech 1949-50).

In 1955, during the time of the second parliament under the United National Party (UNP), the first expanded policy statement on foreign investment was presented to the Parliament by the Finance Ministry under the document entitled "Government Policy in Respect of Private Foreign Investment in Ceylon". It was the first comprehensive policy statement on this matter and it reflected the same open 'open door' attitude as was expressed by the earlier Budget Speech. This policy statement specified the government's policy regarding some area, such as the generation of partnership between foreign and local capital, the employment of local materials, exchange restrictions on the movement of funds, taxation, the allocation of raw materials, and labour and the problem of future nationalization.

The Ten Year Plan (1959-68) contained policy statements of foreign investment which were more specific and more detailed. The Plan called for political guarantees against unwarranted nationalization, along with specific incentives. It also stated the state's position regarding adequate compensation that could freely be remitted from the country in case of nationalization. The purpose behind this might have been to assure the foreign investor that the populist sentiments prevailing in the country after the establishment of the new government in 1956 did not pose any threat to them. Some of the thinking included in the plan was influence by the ideas of foreign economists who visited the country during this period. According to the Ten Year Plan, foreign investments are desirable specially for the process of industrialization in developing countries; direct investments are preferable to loan arrangements; it is best to invite on a somewhat temporary basis, where the investor will begin a project, continue to work on it for some times getting a return on their investment during this time and then transfer ownership after a certain period to local hands. The sentiments of the Ten Year Plan were reiterated in the Budget Speech of 1960 with an important clarification. Certain industrial sectors were reserved for the state sector. This was the beginning of the expansion of the state sector in industrial development. Apart from this, foreign investment were welcomed and the government gave guarantees regarding the repatriation of profit.

The prevailing positive attitudes towards foreign investment that were reflected in these documents ran into difficulties due to foreign exchange problems faced by the country in the 1960s. In his maiden Budget Speech of 1964-65, N.M. Perera as the Finance Ministry declared a moratorium on all remittance of profits, dividends, interest and other investment income for a period of one year in the first instance. Similar curbs were introduced on the transfer of capital by the budget. Announcement were made about amendments to the exchange control act and Import control legislation in order to curb import and exchange malpractices. These measures directly affected the investment climate of the country.

The United Nation Party government came in to power in 1965 and action was taken to mend Sri Lanka's image in the eyes of foreign investors in order to encourage an inflow of capital to ameliorate the adverse effect on industrialization of the foreign exchange shortage. It was announce in the 1965 Budget Speech that the moratorium on dividends payable abroad would be removed in stages and in March 1966 the government published a White Paper entitled "Government Policy on Private Foreign Investment". The White Paper had the effect of narrowing the exclusive domains of public enterprise, as determinant under the previous government. Certain basic industries viz. Cement, Ceramics, Paper, Mineral sands, Caustic soda and Chlorine, Plywood, Steel, Tyres and Tubs, Fertilizers and Petroleum were to remain in the state sector, through the White Paper stated that the proposal of private foreign participation in these industries which would be considered. In the rest of the industrial sector, foreign participation was particularly welcomed in the production of import substitute and of goods with export prospects. The role of FDI in the export development drive received official recognition for the first time in this White Paper which spelt out the 'ability to export a greater part of output' As the most important criterion of the foreign investment approval procedures. The White Paper stated that once approved, the foreign investor enjoy the following benefits:

i. Free remittance of interest, profit and dividends.

ii. Free remittance of proceeds of the sale of liquidation of investments.

iii. Freedom to employ foreign managerial and technical personnel, though Ceylonese substitutes should be progressively trained and employed.

iv. Limited but reasonable remittance of funds for the maintenance of foreign personnel.

v. Free remittance of reasonable royalty payments, technical service fees, etc.

vi. Transference abroad of the savings of the foreign personal on retirement.

vii. Security from expropriation and any form of discriminatory treatment. It is further stated that there is no intention to nationalize any private undertakings, but if this was to become necessary, prompt, effective and adequate compensation would be paid.

The White Paper not only restored the earlier attitude towards foreign investment but also began to set the trends that continue even today. The key aspects of this trends was the laying of emphasis on exportorientation in attracting foreign investment, and also the emergence of new areas such as tourism and fishing for 
foreign investors. The idea of export processing zones appeared for the first time in the 1966 White paper. A Foreign Investment Advisory Committee (FIAC) was set up at the Ministry of Planning to function as the official body in charge of approving and monitoring FDI.

With the change of government in 1970, the foreign investment approval procedure turned out to be more selective and stringent. However, in line with the government's commitment to the export diversification drive, export oriented foreign investment was accorded preferential treatment. The Five Year Plan (1972-76) had a section on the role of foreign investment and subsequently the government issued a White Paper on foreign investment in 1972. As far as fundamental principles were concerned these documents also continued the trend set in 1966, the emphasis on export orientation and the opening up of areas such as fishing and tourism for foreign investors were clearly seen. The idea of Export Processing Zone was more concrete, with Thrincomalee being mentioned as possible site. The difference between these documents and those of 1966 was in the inclusion of several additional criteria in considering the investments. Such criteria as the use of local raw materials, and the use of intermediates technology were included. A package of production and incentive s for export oriented firms introduced by the Five Year Plan.

The policy shift in favour of export oriented foreign direct investment since mid-1960's, however, occurred in an overall policy and political context which was highly unfavourable to private sector in general and export production in particular. Reflecting the cumulative impact of stringent trade controls, high exports taxes and overvalued exchange rate, the overall incentive structure of the economy was characterized by a significant 'anti-export bias' throughout this period.

The government in power during 1970-77, in compliance with its election promise of 'the establishment of the socialist society', acted to consolidate the dominance of the public sector in the economy. The increased government intervention, coupled with various controls, effectively marginalised the private sector in the economy. Despite the policy rhetoric of promoting FDI in practice, the government vacillated between a perceived need for and political suspicion of FDI. For instance, in 1974, the Ministry of Planning came up with a plan for setting up an Export Processing Zone in Trincomalee, but it did not received Cabinet approval because of strong opposition by the left of centre members in the coalition on grounds that it posed a threat to national sovereignty. In approving foreign investment in export oriented ventures, the government's preference was for joint ventures with capital participation of government corporations and foreign manufacturing firm. The perceived crowding out effect on indigenous industry was a major consideration in approving private sector joint ventures. For instance, according to ministry of industry records, at least 17 jointventure proposals to set up export-oriented garment factories were rejected during the period 1970-76 on the ground that [purely locally owned companies could succeed without foreign capital in this diffused-technology product area.

\section{Policies after 1977}

The change of the government in 1977 marked a turning point in economic policies in Sari Lanka. It was realized that the restrictive policies that were followed during the earlier period constrained domestic economics activities and resulted in a slow growth process, In order to revitalize the economy, therefore, action was taken to dismantle administrative controls and to encourage private sector production activities. The promotion of export-oriented FDI turned out to be a pivotal element in the new policy.

The most important single effort at promoting FDI was the setting up of the Greater Colombo Economic Commission (GCEC) in 1978 with wide-ranging powers to facilitate FDI in fully export-oriented ventures. The GCEC was empowered to approve foreign investment in Export Processing Zones (EPZs), which were to be specially design to serve as foci for the development of infrastructure to the standard required by the export-oriented firms, or in locations with in an area of authority covering approximately 160 square miles situated north of Colombo. The incentive package offers by GCEC included: complete foreign ownership facility in investment projects, a tax holiday for up to 10 years with complete tax exemption for remuneration of foreign personnel employed, royalties, and dividends of shareholders during that period; and duty exemption for importation of equipment, construction material and production inputs. Subsequently, GCEC firms were provided with unlimited access to foreign currency credit at interest rates prevailing in world financial markets, under the Foreign Currency Banking Units (FCBU) scheme introduced in 1979. In addition to these incentives, firm located within EPZs are provided with industrial services - serviced sites, building plants, power, water and telecommunication services at subsidized rates and assistance with customs clearance procedures.

The Katunayaka Export Processing Zone (KEPZ) was established in 1978 on site of 200 hectares as the first export promotion zone in the country. It is located near the Katunayake International Airport which has locational advantages for foreign investors who required air transportation for both imports and exports. The second EPZ was set up in 1985, at Biyagama on site of 140 hectares. Both these zones provide infrastructural facilities developed to international standard, with low cost, easily buildable land, reliable sources of power and water, sophisticated security systems, and modern telephone services which include direct dialling, telex and 
facsimile. The EPZs also provide an on-site administration complex with banks, customs, a medical clinic, a post office, sports facilities and cargo forwarding agencies. Commencing initially with the garment industry, these zones have diversified into a range of other products such as leatherwear, gloves, electronics, horticultural products, security printing, ship repairs, jewellery, gems and diamonds, plastics, etc.

In June 1991 the GCEC launched its third Export Processing Zone in Kogalla, 80 miles South of Colombo, on a land area of 80 hectares. The fourth industrial estate was established in 1994 at Pallekele, Kandy, developing an area of approximately 250 acres. Unlike other three Export Processing Zones, the industrial park at Kandy was planned to accommodate both foreign investment projects. Hence it was named as an Industrial Park. The fifth industrial estate was established in 1996 at Attanagalla with the aim of developing 10 industrial plots. The BPI has taken further steps to setup mini export processing zones in Malwatta, Mirigama and Watupitiwala by providing the requires infrastructural facilities The Malwatta mini EPZ will accommodate 11 industries, after completion of its construction work. The Mirigama mini EPZ, extending over 40 hectares has a capacity for 15 industrial units. The wathupitwala mini EPZ is expected to be completed in mind 1999. The Wathupitiwala mini EPZ consists of 27 hectares for 20 industrial plots.

The fiscal incentives and other concessions applicable to foreign investment in area and enterprises under GCEC law are summarized as follows:

i. 100 percent tax exemption on corporate income for between 5-15 years, reckoned from the first the first profit making year.

ii. Concessionary tax of 2 percent to 5 percent for further 15 years after expiry of the tax holidays

iii. No income tax on the remuneration of foreign personnel during the tax holiday period.

iv. Free remittance of earnings of foreign personnel.

v. Double taxation relief on earnings of expatriates from countries with which Sri Lanka has entered into Double Taxation Relief Agreements.

vi. Free repatriation of capital and proceeds on liquidation.

vii. Exemption from controls on imports, exports, transfer of shares and dividends, transfer of capital and proceeds, on liquidation etc.

viii. No tax on royalties and dividends of resident and non-resident shareholders during the tax holiday period

ix. No ownership restrictions - no limits on the ownership of equity of foreign investors.

$x$. Free transfer ability of shares within and outside Sri Lanka

xi. No tax on the transfer of shares

xii. Duty free imports of construction materials, raw materials, plant, equipment and other project related to goods.

xiii. Duty free exports.

Subsequently after 15 year of liberalization, the granting of tax holidays was done away with and replaced by a 15 percent preferential tax for a period of 20years. Duty free imports and exports to enclave areas were permitted.

While GCEC package was to act as the major set of instruments for promoting export oriented industrialization, many elements of the 1977 policy package were aimed at improving the general investment climate in the country for both local and foreign firms. These elements included the removable of most quantitative restrictions on import trade, considerable relaxation of controls on capital and profit repatriation and exchange rate depreciation. With regards to these concessions and incentives, the non-GCEC (i.e. FIAC approved) joint venture firms were treated equally with locally owned firms. There was no major change in the policy towards foreign ventures which do not meet the criterion of 'full' export-orientation. Such project had to go through the normal approval procedure of FIAC. Majority local ownership continued to be the general rule of approving such projects. However under the new policy emphasis on export oriented industrialization, FIAC was empowered to adapt more liberal ownership criteria (going even up to 100 percent foreign ownership) depending on the export potential of the projects. As an important part of FDI policy, steps were also taken to enter into Investment Protection Agreements and Double Taxation relief Agreement with major investing countries. The former agreements were further granted by Article 157 of the Constitution of Sri Lanka.

In addition to these policy initiatives, which foreign investors generally found highly attractive, the potential climate of the country during the first six years or so after the general election of 1977 was also much in line with the investor expectations. After the election of 1977 was also defeat in 1977, the traditional opposition was disarray, and the decline of the left-wing parties was accompanied by the weakening of trade unions. In July 1980, the government crushed a major public sector strike using emergency powers and the police, and no major trade union challenge emerged in subsequent years. All in all, during the immediate post1977 years Sri Lanka scored well on various factors relevant to foreign investors 'perceptions; the international news media soon dubbed Sri Lanka 'the new investment centre of Asia'. 
The investment climate, however did not remain that favourable for long. Debilitating elements were to emerge on many fronts. In the sphere of macroeconomics management, the government commitments to a massive public sector investment programme aggravated the fiscal imbalance, raised costs of domestic resources and generally increased inflationary pressures in the economy. In the political arena, sigs of policy instability resulting from internal power struggles within the ruling party were to emerge by 1982. The major blow however, came with the escalation, since 1983, of the long-standing political rivalry between the two major ethnic groups in the country. Gradually over time, this conflicts led to extensive civil war with in the north and the east of the country. Largely due to Indian government pressures, the Sri Lankan regime in power decided to introduce, through the provincial council system a political solution was sought to the problem of escalated civil war conditions in the above areas of the country. The make thing worse, the above constitutional reform proved to be a catalyst for the eruption of a wide-spread armed insurrection launched by radical Sinhala extremists in the rest of the country. In the years 1987-89 witnessed the entire socio-politico-economic system in the country getting into turmoil and crisis. In the face of controlling political instability there was little scope for economic policy.

In 1989, the government managed to restore some political stability within the country outside the Northern and Eastern provinces by violently crushing the rebellion in the rest of the country. The post-1989 years have anyway seen a more vigorous adoption of market-oriented policies. These policy initiatives included an ambitious privatisation programme, a rationalization of the tariff controls except those on a limited range of strategic items, the removable of exchange controls on current account transactions in successive stages culminating in the abolition of foreign exchange surrender requirement on export transactions in March 1993, and permitting all BOI approved exporters to borrow foreign currencies from FCBUs for the purpose of financing imports required to execute export orders.

In the sphere of FDI promotion, FIAC was abolished and its activities were placed under GCEC in January 1990, with a view to creating a 'one stop investment promotion centre' which could facilitate and speed up investment approval within a unified policy framework applicable to both import-substituting and exportoriented investors. The reformed GCEC was named the Board of Investment (BOI) in November 1992. A new investment policy statement was announced in November 1990 introduced several important changes to the foreign investment policy framework; first, the historical reliance on the case-by-case approval procedure was abandoned and a new system based on the concept of automatic investment approvals was introduced; second, various restriction on the activities and ownership structures of joint-ventures were lifted; third, foreigners were permitted to purchase up to 40 percent of shares of existing quoted companies without approval; and fourth, the GCEC was empowered to private free-trade zones status to foreign investors in all parts of the country in order to facilitate the development of close linkages between the FDI activities and the domestic economy at large.

The favourable developments notwithstanding, Sri Lanka still far short of regaining the 'investmentcentre-in-Asia' image which prevailed in the immediate aftermath of the 1977 policy reforms. There are many disturbing elements which hinder foreign capital participation in the economy, particularly in long term ventures. The ethnic conflicts seems to defy any quick political solution, and the economy continues to be burdened by the massive defence expenditures and their consequences for macroeconomic stability.

\section{Policies After 2000}

The adversative effect of the September 11 attack in 2001 to pentagon was cause to felt down FDI flows in Sri Lanka. Furthermore, same year there was LLTE attacked to Sri Lanka international airport, those are adversely affected to the FDI flows. After 2002 slightly favourable economic environment was visible in the country due to the peace agreement with the LTTE. Although the LTTE withdrew from negotiations and the government decided to crush the rebels in 2005, FDI flows into the sector have shown a steady growth over 2003-2010 (Thilakaweera, 2011)

In 2006, the country received the highest-ever FDI inflows, surpassing the previous highest level recorded in 1997. The total FDI inflows reached the highest-ever level of US dollars 604 million in 2006, surpassing the previous record level of US dollars 450 million in 1997, which included privatisation proceeds of around US dollars 301 million. The increased investment flows could be attributable to the substantial increase in reinvestment of retained earnings by the existing BOI companies, especially those in the services sector, and new initiatives by the BOI to attract higher investments including the setting up of 300 factories in less developed regions under its Nipayum Centre programme. The FDI inflows consist of equity capital of US dollars 81 million, loans and advances of US dollars 75 million by the shareholders, foreign loans of US dollars 124 million and the reinvestment of retained earnings of US dollars 324 million by the existing companies. The acceleration of the basic infrastructure development in the form of roads, highways and power supply, etc., while maintaining an enabling business environment that ensure property rights, sound and fast dispute settlement and a greater labour mobility, would help achieve even higher levels of FDI. Meanwhile, FDI 
outflows decreased to US dollars 30 million in 2006 from US dollars 38 million in 2005 as only a few selected local companies invested abroad during the year. (Central Bank of Sri Lanka, 2006)

An increasing tendency in Foreign Direct Investments (FDIs) can be seen in 2007 and reached US\$ 734 million, more than US \$ 130 million above 2006 recorded level. Sri Lanka achieved this FDIs level without any proceeds from privatization of government enterprises and improved the investor sureness in county long term development expectation. That increasing trend in Foreign Direct Investment continued in 2008 and reached to US dollar 889 million, more than US \$ 150 million above the level recorded in 2007. The significant development should be viewed in the backdrop of financial turmoil, the world is experiencing and the absence of any proceeds from privatization of government enterprises. This reflects the continuous investor confidence in long-term development projects in the country.

In 2007, the FDI inflows exceeded the previous peak level recorded in 2006 reflecting the incessant investor confidence on the Sri Lankan economy and the prevailing investor friendly investment regime in the country. The gross FDI inflows with the foreign loans gained by the companies which approved by BOI reached a best level of US dollars 734 million in 2007 from US dollars 604 million in 2006, because of shrill increase in reinvestment of retained earnings by present BOI companies. Nipayum Centre programme which was initiated by BOI companies have promoted investment in fewer developed areas has also contributed to the greater investment flows in 2007. To attract higher level of foreign investment, county should increase basic infrastructure such as roads, highways and power supply to international standards and promote more PublicPrivate Partnership arrangements in major infrastructure projects that are currently undertaken solely by the government with borrowed funds. It is also essential to create an enabling business environment that safeguard property rights, faster allocation of lands for new investments, sound and fast dispute settlement and greater labour mobility to achieve higher levels of FDI (Central Bank of Sri Lanka, 2007)

In year 2008, FDI inflows recorded higher level than 2007 mainly as a result of improved reinvestment of retained earnings. (Central Bank of Sri Lanka, 2008)

FDI together with loans during 2009 diminished to US dollars 601 million after reaching a record high of US dollars 889 million in 2008, global financial crisis on the foreign financial flows was the main reason for this decrement. The global financial recession caused in the drying-up of novel equity investments and foreign loans directed to the FDI initiatives. The maximum FDI inflow was received from China, that is US dollars 145 million and UK and India FDI inflows were US dollars 80 million and US dollars 78 million, respectively. Through telecommunications, power and energy industries earned more FDI inflows from China, UK and India. For the meantime, FDI outflows declined to US dollars 20 million in 2009 from US dollars 62 million in 2008. Lower realisation of the outward FDI projects approved in previous years reflecting the influence of the global financial crisis was the main cause for this (Central Bank of Sri Lanka, 2009) Again FDI recorded level including loans was decreased during 2010 to US dollars 516 million from US dollars 601 million in 2009. Even though in nature FDI is long-term, comparable to year 2008 the influence of the global financial crisis on foreign equity and debt inflows continued to have an effect on the FDI. However, the increase in the reinvestment of retained earnings indicates signs of recovery in FDI. (Central Bank of Sri Lanka, 2010)

Sri Lanka documented the uppermost FDI inflows in 2011. FDI improved to US dollars 1,066 million in 2011 related to US dollars 516 million in 2010. During the year, US dollars 110 million of loans were received by the Board of Investment (BOI) approved companies, compared to US dollars 39 million in 2010 (Central Bank of Sri Lanka, 2011).

FDI sustained to be a main inflow to the financial account of the BOP notwithstanding global economic performance. FDI with loans received by the BOI approved companies, recorded its maximum inflow in year 2012, it is US dollars 1,338 million. Following reasons were caused to improvement of FDI

i. Investor confidence in the long-term investment potential in key emerging sectors

ii. Macroeconomic stability in the country.

FDI sector wise composition continued to reflect increased investments in large scale development projects and developing sectors. Highest share of FDI that is 44.6 per cent received from Infrastructure sector with key investments in ports and container terminals, telephone and telecommunication networks, power generation and housing and property development. 31.9 per cent of FDI attract from service sector in 2012 and 8.8 per cent for the tourism sector and the manufacturing sector attracted 23 per cent of FDI in 2012. Due to the enlargement of the tourism industry and improved foreign investment in education, communication and information technology sectors, more direct investment is expected in 2013 and beyond. FDI outflows increased to US dollars 85 million in 2012 from US dollars 60 million in 2011. (Central Bank of Sri Lanka, 2012)

Foreign direct investment maintain stable position in 2013 with the steady retrieval in the global economy and improved stable macroeconomic environment. Total direct investment was US dollars916 million in year 2013 (Central Bank of Sri Lanka, 2013) 
Total foreign direct investment remain strong in year 2014. Total foreign direct investment related inflows was US dollars 1,685 million in 2014 with respect to the US dollars 1,437 million in 2013. Direct investment related inflows are as follows;

Infrastructure sectors $\quad-\quad 42.2$ per cent

Services sectors $\quad-\quad 36.8$ per cent

Manufacturing sector $\quad-\quad 20.7$ per cent

(Central Bank of Sri Lanka, 2014)

Total foreign direct investment was decreased significantly in 2015. Total FDI inflows along with foreign loans was 1,161 million, in 2015. This was a sharp moderation compared to the US dollars 1,635 million and US dollars 894 million, respectively, recorded in 2014. The decline in FDIs in 2015 can be attributed to several reasons.

1. Two national elections held during the year prompted investors to adopt a wait and see approach until the political environment stabilises.

2. Numerous investors were unwilling to invest in emerging markets in the backdrop of continuous outflows, particularly from securities markets of emerging economies.

3. The suspension of the Colombo Port City project due to the government's decision to review the project, also adversely affected FDI inflows during the year

(Central Bank of Sri Lanka, 2015)

\section{Conclusion}

Foreign capital plays an important role in raising investment levels so as to accelerate economic growth in Sri Lanka as in the case of other developing countries. In the present study, an attempt was made to investigate the pattern and policy on foreign direct investment in Sri Lanka, during the period of 1949-2015. The response by foreign investors to the economic policy took place in 1977 was remarkable. Between 1979 and 1997, FDI inflows have ranged from maximum of 2.02 percent of GDP in 1993 to a minimum of 0.06 percent of GDP in 1978 with the average for the period remaining at 1.0 percent of GDP.

In year 2001 Foreign Direct Investment felt down due to the impact of September 11 attack to pentagon and LTTE attacked to the Sri Lanka International Airport. After 2002 Foreign Direct Investment slightly increased because of the peace agreement with LTTE. There were increasing trend in Foreign Direct Investment to 2008 as the results of improve investment of retain earnings, but in year 2009 Foreign Direct Investment was diminished as a result of global financial crisis. Even though Sri Lanka reached highest level of Foreign Direct Investment in year 2014 mainly due to the steady macroeconomic environment, in year 2015 of Foreign Direct Investment significantly fallen down by reason of two national elections which held during year 2015, Investors unwillingness of investing emerging markets and suspension of the Colombo Port City project.

\section{References}

[1]. Central Bank of Sri Lanka. (2006). Annual Report. Colombo: Central Bank of Sri Lanka.

[2]. Central Bank of Sri Lanka. (2007). Annual Report. Colombo: Central Bank of Sri Lanka.

[3]. Central Bank of Sri Lanka. (2008). Annual Report. Colombo: Central Bank of Sri Lanka.

[4]. Central Bank of Sri Lanka. (2009). Annual Report. Colombo: Central Bank of Sri Lanka.

[5]. Central Bank of Sri Lanka. (2010). Annual Report. Colombo: Central Bank of Sri Lanka.

[6]. Central Bank of Sri Lanka. (2011). Annual Report. Colombo: Central Bank of Sri Lanka.

[7]. Central Bank of Sri Lanka. (2012). Annual Report. Colombo: Central Bank of Sri Lanka.

[8]. Central Bank of Sri Lanka. (2013). Annual Report. Colombo: Central Bank of Sri Lanka.

[9]. Central Bank of Sri Lanka. (2014). Annual Report . Colombo: Central Bank of Sri Lanka.

[10]. Central Bank of Sri Lanka. (2015). Annual Report. Colombo: Central Bank of Sri Lanka.

[11]. Jayathilake, L. V. K (1999), The role of foreign direct investment in export promotion and employment generation in Sri Lanka. The dissertation submitted to the partial fulfilment of the requirements for the posgratuate diploma in businessv statistics, University of Ruhuna, Sri Lanka.

[12]. Thilakaweera, B. (2011). Economic Impact of Foreign Direct Investment, Sri Lanka. 